\title{
Hydroxycalciomicrolite, $\mathrm{Ca}_{1.5} \mathrm{Ta}_{2} \mathrm{O}_{6}(\mathrm{OH})$, a new member of the microlite group from Volta Grande pegmatite, Nazareno, Minas Gerais, Brazil
}

\author{
M. B. Andrade ${ }^{1,2, *}$, H. Yang ${ }^{2}$, D. Atencio ${ }^{3}$, R. T. Downs ${ }^{2}$, N. V. Chukanov ${ }^{4}$, M. H. Lemée-Cailleau ${ }^{5}$, \\ A. I. C. Persiano ${ }^{6}$, A. E. Goeta ${ }^{7, \dagger}$ and J. Ellena ${ }^{1}$ \\ 1 Department of Physics and Interdisciplinary Science, São Carlos Institute of Physics, University of São Paulo, \\ Caixa Postal 369, 13560-970 São Carlos, SP, Brazil \\ 2 Department of Geosciences, University of Arizona, 1040 East 4th Street, Tucson, Arizona 85721, USA \\ 3 Departamento de Mineralogia e Geotectônica, Instituto de Geociências, Universidade de São Paulo, Rua do Lago \\ 562, 05508-080 São Paulo, SP, Brazil \\ 4 Institute of Problems of Chemical Physics, Russian Academy of Sciences, Chernogolovka, Moscow Region 142432 , \\ Russia \\ 5 Institut Laue Langevin (ILL), 6 Rue Jules Horowitz, BP 156 38042, Grenoble, France \\ 6 Departamento de Física, Universidade Federal de Minas Gerais, Avenida Presidente Antonio Carlos 6627 , \\ 30123-970, Belo Horizonte, MG, Brazil \\ 7 Department of Chemistry, Durham University, Durham DH1 3LE, UK
}

[Received 4 January 2015; Accepted 11 May 2016; Associate Editor: Ian Graham]

\section{ABSTRACT}

Hydroxycalciomicrolite, $\mathrm{Ca}_{1.5} \mathrm{Ta}_{2} \mathrm{O}_{6}(\mathrm{OH})$ is a new microlite-group mineral found in the Volta Grande pegmatite, Nazareno, Minas Gerais, Brazil. It occurs as isolated octahedral and as a combination of octahedral and rhombic dodecahedral crystals, up to $1.5 \mathrm{~mm}$ in size. The crystals are yellow and translucent, with a white streak and vitreous to resinous lustre. The mineral is brittle, with a Mohs hardness of 5-6. Cleavage is not observed and fracture is conchoidal. The calculated density is $6.176 \mathrm{~g} \mathrm{~cm}^{-3}$. Hydroxycalciomicrolite is isotropic, $n_{\text {calc. }}=2.010$. The infrared and Raman spectra exhibit bands due to $\mathrm{O}-\mathrm{H}$ stretching vibrations. The chemical composition determined from electron microprobe analysis $(n=13)$ is (wt.\%): $\mathrm{Na}_{2} \mathrm{O}$ 0.36(8), $\mathrm{CaO} 15.64(13), \mathrm{SnO}_{2}$ 0.26(3), $\mathrm{Nb}_{2} \mathrm{O}_{5}$ 2.82(30), $\mathrm{Ta}_{2} \mathrm{O}_{5}$ 78.39(22), $\mathrm{MnO}$ 0.12(2), $\mathrm{F}$ 0.72 (12) and $\mathrm{H}_{2} \mathrm{O} 1.30$ (from the crystal structure data), $\mathrm{O}=\mathrm{F}-0.30$, total 99.31(32), yielding an empirical formula, $\left(\mathrm{Ca}_{1.48} \mathrm{Na}_{0.06} \mathrm{Mn}_{0.01}\right)_{\Sigma 1.55}\left(\mathrm{Ta}_{1.88} \mathrm{Nb}_{0.11} \mathrm{Sn}_{0.01}\right)_{\Sigma 2.00} \mathrm{O}_{6.00}\left[(\mathrm{OH})_{0.76} \mathrm{~F}_{0.20} \mathrm{O}_{0.04}\right]$. Hydroxycalciomicrolite is cubic, with unit-cell parameters $a=10.4205(1) \AA, V=1131.53(2) \AA^{3}$ and $Z=8$. It represents a pyrochlore supergroup, microlite-group mineral exhibiting $P 4_{3} 32$ symmetry, instead of $F d \overline{3} m$. The reduction in symmetry is due to long-range ordering of $\mathrm{Ca}$ and vacancies on the $A$ sites. This is the first example of such ordering in a natural pyrochlore, although it is known from synthetic compounds. This result is promising because it suggests that other species with $\mathrm{P}_{3} 32$ or lower-symmetry space group can be discovered and characterized.

KeYwords: hydroxycalciomicrolite, $\mathrm{Ca}_{1.5} \mathrm{Ta}_{2} \mathrm{O}_{6}(\mathrm{OH})$, pyrochlore supergroup, microlite group, crystal structure, Raman spectra, infrared spectrum.

\section{Introduction}

*E-mail: mabadean@terra.com.br

${ }^{\dagger}$ Deceased

https://doi.org/10.1180/minmag.2016.080.116
Hydroxycalciomicrolite, $\mathrm{Ca}_{1.5} \mathrm{Ta}_{2} \mathrm{O}_{6}(\mathrm{OH})$, from the Volta Grande pegmatite, Nazareno, Minas Gerais, Brazil, is a new mineral (IMA 2013-073) named according to the nomenclature system for the pyrochlore supergroup of minerals approved by 
IMA-CNMNC (Atencio et al., 2010). The general formula of the pyrochlore-supergroup minerals is $A_{2-m} B_{2} X_{6-w} Y_{1-n}$, where $m=0$ to $1.7, w=0$ to 0.7 , $n=0$ to 1 (Lumpkin and Ewing, 1995). In hydroxycalciomicrolite, the $A, B$ and $Y$ sites are dominated by $\mathrm{Ca}, \mathrm{Ta}$ and $\mathrm{OH}$, respectively. The type material is deposited in the Museu de Geociências, Instituto de Geociências, Universidade de São Paulo, São Paulo, Brazil, registration number DR917. Part of the cotype sample has been deposited at the University of Arizona Mineral Museum, RRUFF Project (http:/ rruff.info/R130269).

\section{Occurrence, physical properties, chemical composition and vibrational spectroscopy}

Hydroxycalciomicrolite occurs as an accessory phase in the Volta Grande pegmatite $\left(21^{\circ} 10^{\prime} 08.6^{\prime \prime}\right.$

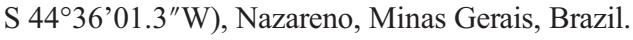
The pegmatites of Volta Grande field, intrusive into Archaean amphibolites (tholeiitic metabasalts), are probably related to the Transamazonian-cycle age Ritápolis granite, which is contemporaneous with the Tabuões trondhjemite, dated by Quéméneur and Vidal (1989) at $1931 \pm 20 \mathrm{Ma}$. The ore extraction process in the Volta Grande mine has been described by Heinrich (1964). In the past the kaolinized pegmatite was hauled by scraper to a hopper where it was washed by means of hoses into a series of sluice boxes in which kaolinite and mica were almost entirely removed along with most of the quartz particles. The residuum of quartz and heavy minerals was further concentrated by washing and then dried before shipment to the separation plant. The concentrate was separated magnetically and electrostatically into fractions: (1) cassiterite; (2) 'tantalite'; (3) 'microlite' ('djalmaite'); and (4) ilmenite + 'garnet'. Some papers on the Volta Grande pegmatites present no paragenetic data as they have been based on these minerals concentrates (e.g. Guimarães, 1950; Francesconi, 1972; Francesconi et al., 1976). Several minerals were identified in the concentrates: albite, almandine, 'amphibole', beryl, bityite, brookite, cassiterite, epidote, fluorite, fluorapatite, gahnite, goethite, hematite, ixiolite, 'lepidolite', magnetite, microcline, 'microlite' monazite-(Ce), muscovite, 'pyrochlore', quartz, rutile, samarskite-(Y), spodumene, tantalite-(Mn), 'tourmaline', 'varlamoffite', xenotime-(Y) and zircon. Hydroxycalciomicrolite (10 crystals) was separated from an old concentrate, labelled 'djalmaite', from the Museu de Geociências, Universidade de São Paulo, without the details of donor registration. Hydrokenomicrolite (Andrade et al., 2013a) and fluorcalciomicrolite (Andrade et al., 2013b) are also from the same concentrate. So no paragenetic data can be presented for these minerals. Information concerning mineralogical parageneses were summarized by Pires and Cabral (1998). The pegmatites of the Rio da Mortes tin district (Rolff, 1948) were first investigated by Guimarães and Guedes $(1944,1946)$, who recorded the following mineralogical distribution in outcrops of the pegmatite along its strike from Rio das Mortes towards Fazenda Volta Grande, after which the pegmatite bodies were collectively named: $80 \mathrm{~m}$ of $\mathrm{cm}$-sized crystals of spodumene and feldspars, $300 \mathrm{~m}$ of coarse-grained cassiterite, muscovite and quartz, followed by $30 \mathrm{~m}$ of $\mathrm{mm}-$ sized crystals of lepidolite. Relics of spodumene enclosed in quartz and microcline, or in a micaceous aggregate, were found in the spodumene-poor zones. These authors proposed two stages of pegmatite formation: (1) calcic-sodic stage, marked by crystallization of oligoclase, to which cassiterite and spodumene are probably related; and (2) a potassic stage, responsible for the formation of microcline and muscovite, both along with quartz, at the expense of oligoclase and spodumene, respectively. Spodumene may be replaced by quartz with formation of lepidolite (Guimarães 1948, 1950). The paragenetic relations amongst ore (opaque) minerals were established by Guimarães (1950). He concluded that tantalite was contemporaneous with cassiterite; 'uranmicrolite' formed later, as indicated by the inclusion of cassiterite grains in the latter. Further textural evidence demonstrated that replacement of tantalite by microlite occurred (Peixoto and Guimarães, 1953). Whether tantalite altered to microlite or 'uranmicrolite' was attributed to the local availability of uranium in the hydrothermal solution (Belezkij, 1956; Guimarães and Belezkij, 1956). A similar paragenetic sequence in two stages was proposed by Heinrich (1964): (1) magmatic, with quartz, muscovite, microcline, spodumene, sodic plagioclase, cassiterite and tantalite as main phases; and (2) hydrothermal, characterized by lepidolite and microlite, and barian microlite (which is intergrown with microlite and replaces it). $\mathrm{He}$ considered that several of the pegmatite bodies were the result of two or more periods of injection of pegmatite-forming magma. The calcic-sodic stage advanced by Guimarães and Guedes (1944) was not recognized by Heinrich (1964); however, 
Francesconi (1972) characterized the existence of the calcic-sodic stage, and attributed it to a final alkaline stage $(\mathrm{K}, \mathrm{Li}, \mathrm{Rb}, \mathrm{Cs})$ forming lepidolite, bityite, microlite and zircon (now metamict). Although Heinrich (1964) stated that nearly all pegmatites are either unzoned or indistinctly zoned, the distribution of spodumene, lepidolite and muscovite recorded by Guimarães and Guedes (1944, 1946) is suggestive of zoning of the bodies. At the Volta Grande mine, a well-defined lepidolitespodumene boundary can be traced along ore bodies (Pires and Pires 1992). Internal zoning in the pegmatites has been reported by Quéméneur (1987). The Volta Grande pegmatites present a particular zonation. This consists of an aplitic zone of fine-grained albite in the border, which wraps a principal mass of granitoid composed of spodumene, quartz, albite, microcline and muscovite. At the centre of this granitoid zone, a lenticular layer ( 0.5 to $3 \mathrm{~m}$ thick) exists, composed of large spodumene crystals and intergranular quartz. In the central part, the ore bodies also contain compact lepidolite lenses. These pegmatites are mined for tin and tantalum and are characterized by their enrichment in rubidium $\left(0.8 \% \mathrm{Rb}_{2} \mathrm{O}\right.$ on average in the bulk composition). A contact aureole is welldeveloped and affects the wall rock amphibolite to a thickness of 2 to $3 \mathrm{~m}$. This aureole does not contain tourmaline, and contains two distinct facies: a thin layer of zinnwaldite glimmerite $(2 \mathrm{~cm}$ thick, locally with some pockets $>100 \mathrm{~cm}$ thickness), and a facies with holmquistite and scattered zinnwaldite of 1 to $3 \mathrm{~m}$ thick that passes into fresh amphibolite (Quéméneur and Lagache, 1994). No propylitic alteration was observed (Quéméneur and Lagache, 1999). Data on the microlite-group minerals were obtained by Pinto (2000). Hafnon from the Volta Grande pegmatite was described by Pereira et al. (2002, 2003, 2004).

Hydroxycalciomicrolite occurs as isolated octahedral and as a combination of octahedral and rhombic dodecahedral crystals, up to $1.5 \mathrm{~mm}$ in size (Fig. 1). The mineral is yellow and translucent, with a white streak and vitreous to resinous lustre. The mineral is colourless under plane-polarized light. No anomalous anisotropy was noted. It is non-fluorescent under short- and long-wave ultraviolet light. It does not exhibit cathodoluminescense under an electron microprobe beam. The mineral is brittle, with a Mohs' hardness of 5-6 and conchoidal fracture. Cleavage was not observed. The calculated density is $6.176 \mathrm{~g} \mathrm{~cm}^{-3}$, based on the empirical formula and unit-cell parameters obtained from the single-crystal X-ray diffraction

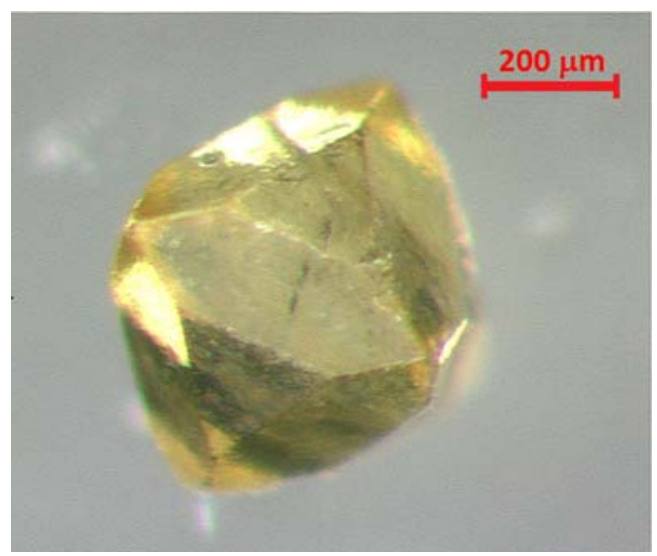

FIG. 1. Hydroxycalciomicrolite crystal from Nazareno, Minas Gerais, Brazil.

data. Optically, the mineral is isotropic. The refractive index calculated from the GladstoneDale relationship is $n_{\text {calc. }}=2.010$ (higher than that of readily available immersion liquids).

The chemical composition of hydroxycalciomicrolite was determined using a CAMECA SX50 electron microprobe $(25 \mathrm{kV}, 20 \mathrm{nA}, 1 \mu \mathrm{m}$ beam diameter) with a dwell (peak) time of $20 \mathrm{~s}(10 \mathrm{~s}$ on backgrounds) for all elements. Investigation using back-scattered electrons (BSE) (Fig. 2) showed that the sample is homogenous and wavelengthdispersive spectroscopy was used (Jercinovic et al., 2012) to determine the presence of trace elements $(<0.1 \mathrm{wt} \%)$ with a detection limit of $0.03 \mathrm{wt} . \%$. The standards included albite $(\mathrm{Na})$, diopside $(\mathrm{Ca})$, cassiterite (Sn), $\mathrm{LiNbO}_{3}(\mathrm{Nb}), \mathrm{LiTaO}_{3}(\mathrm{Ta})$, rhodonite (Mn) and $\mathrm{MgF}_{2}(\mathrm{~F})$, yielding an

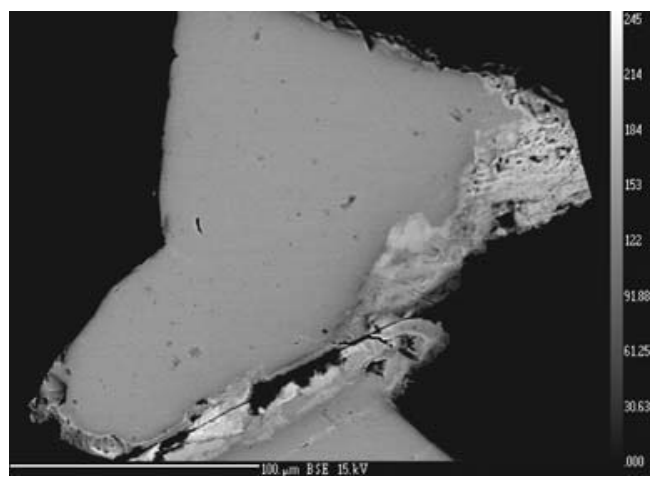

FIG. 2. Backscattered electron image of the hydroxycalciomicrolite grain analysed in this study. 
TABLE 1. Powder X-ray diffraction data for hydroxycalciomicrolite (indexed with $a=10.4280(8) \AA$ )* and for fluorcalciomicrolite (Andrade et al., 2013b) (indexed with $a=10.417(1) \AA$ )*.

\begin{tabular}{|c|c|c|c|c|c|c|c|c|}
\hline \multicolumn{3}{|c|}{ Hydroxycalciomicrolite } & \multicolumn{6}{|c|}{ Fluorcalciomicrolite } \\
\hline$I_{\text {rel }}$ & $d_{\text {meas. }}(\AA)$ & $d_{\text {calc. }}(\AA)$ & $I_{\text {rel }}$ & $d_{\text {meas. }}(\AA)$ & $d_{\text {calc. }}(\AA)$ & $h$ & $k$ & $l$ \\
\hline 1 & 7.367 & 7.374 & & & & 1 & 1 & 0 \\
\hline 100 & 6.025 & 6.021 & 59 & 5.997 & 6.014 & 1 & 1 & 1 \\
\hline 1 & 4.661 & 4.664 & & & & 2 & 1 & 0 \\
\hline 1 & 4.255 & 4.257 & & & & 2 & 1 & 1 \\
\hline$<1$ & 3.677 & 3.687 & & & & 2 & 2 & 0 \\
\hline 15 & 3.145 & 3.144 & 83 & 3.138 & 3.141 & 3 & 1 & 1 \\
\hline 73 & 3.010 & 3.010 & 100 & 3.005 & $\mathbf{3 . 0 0 7}$ & 2 & 2 & 2 \\
\hline 7 & 2.606 & 2.607 & 29 & 2.602 & 2.604 & 4 & 0 & 0 \\
\hline 2 & 2.391 & 2.392 & 14 & 2.389 & 2.390 & 3 & 3 & 1 \\
\hline 7 & 2.006 & 2.007 & 23 & 2.004 & 2.005 & 5 & 1 & 1 \\
\hline 7 & 2.006 & 2.007 & & & & 3 & 3 & 3 \\
\hline 8 & 1.843 & 1.843 & 23 & 1.841 & 1.8415 & 4 & 4 & 0 \\
\hline 4 & 1.762 & 1.763 & 13 & 1.760 & 1.7608 & 5 & 3 & 1 \\
\hline 2 & 1.591 & 1.590 & 25 & 1.589 & 1.586 & 5 & 3 & 3 \\
\hline 5 & 1.572 & 1.572 & 17 & 1.571 & 1.5704 & 6 & 2 & 2 \\
\hline 4 & 1.505 & 1.505 & 24 & 1.504 & 1.5036 & 4 & 4 & 4 \\
\hline 2 & 1.460 & 1.460 & & & & 1 & 5 & 5 \\
\hline 2 & 1.460 & 1.460 & 21 & 1.459 & 1.4587 & 1 & 1 & 7 \\
\hline 2 & 1.358 & 1.358 & 7 & 1.356 & 1.3562 & 1 & 3 & 7 \\
\hline 2 & 1.358 & 1.358 & & & & 3 & 5 & 5 \\
\hline
\end{tabular}

*Calculated data were obtained using CELLCALC software (Miura, 2003).

The strongest lines are given in bold.

average composition (wt.\%) (13 points in one grain) of $\mathrm{Na}_{2} \mathrm{O} \quad 0.36(8), \quad \mathrm{CaO} \quad 15.64(13)$, $\mathrm{SnO}_{2}$ 0.26(3), $\mathrm{Nb}_{2} \mathrm{O}_{5}$ 2.82(30), $\mathrm{Ta}_{2} \mathrm{O}_{5}$ 78.39(22), $\mathrm{MnO} 0.12(2), \mathrm{F} 0.12(12)$ and $\mathrm{H}_{2} \mathrm{O} 1.30$ (from the crystal structure data $),(\mathrm{O}=\mathrm{F})-0.30$, total $=99.31$ (32). Sodium was analysed before any of the other elements for each spot analysis to prevent volatilization.

The resultant chemical formula, calculated on the basis of 2 cations per formula unit at the $B$ site is $\left(\mathrm{Ca}_{1.48} \mathrm{Na}_{0.06} \mathrm{Mn}_{0.01} \square_{0.45}\right)_{\Sigma 2.00}\left(\mathrm{Ta}_{1.88} \mathrm{Nb}_{0.11} \mathrm{Sn}_{0.01}\right)_{\Sigma 2}$ $\mathrm{O}_{6}\left[(\mathrm{OH})_{0.76} \mathrm{~F}_{0.20} \mathrm{O}_{0.04}\right]$, which can be simplified to the charge-balanced end-member $\mathrm{Ca}_{1.5} \mathrm{Ta}_{2} \mathrm{O}_{6}(\mathrm{OH})$. This ideal formula corresponds to the following oxide weight percentages: $\mathrm{CaO}=15.72, \mathrm{Ta}_{2} \mathrm{O}_{5}=82.60$, $\mathrm{H}_{2} \mathrm{O}=1.68$, total 100.00 .

The Raman spectrum of hydroxycalciomicrolite was collected from a randomly oriented crystal on a Thermo-Almega microRaman system, using a $532 \mathrm{~nm}$ solid-state laser with a thermoelectric cooled CCD detector. The laser is partially polarized with $4 \mathrm{~cm}^{-1}$ resolution and a spot size of $1 \mu \mathrm{m}$.

The infrared (IR) absorption spectrum of hydroxycalciomicrolite was obtained from a powdered sample (mixed with $\mathrm{KBr}$ and pelletized) using a Bruker Alpha FTIR spectrometer, with resolution $4 \mathrm{~cm}^{-1}$.

\section{X-ray and neutron crystallography}

The powder X-ray diffraction data of hydroxycalciomicrolite were obtained using a Bruker D8 Advance DaVinci diffractometer with $\mathrm{CuK \alpha}$ $(\lambda=1.54058 \AA)$ radiation. Unit-cell parameters refined from the powder data are $a=10.4280(8)$ $\AA$ and $V=1134.0(2) \AA^{3}$. Powder X-ray diffraction data for hydroxycalciomicrolite and fluorcalciomicrolite are compared in Table 1. Some forbidden lines for $F d \overline{3} m$ are observed in hydroxycalciomicrolite: (110), (210) and (211).

A single crystal of hydroxycalciomicrolite with dimensions $0.05 \mathrm{~mm} \times 0.04 \mathrm{~mm} \times 0.02 \mathrm{~mm}$ was used for the structural investigation. X-ray diffraction measurements were made on a Bruker X8 APEX2 CCD diffractometer with graphite monochromatized $\mathrm{MoK} \alpha$ radiation with frame widths of $0.5^{\circ}$ in $\omega$ and $30 \mathrm{~s}$ counting time per frame. The 
TABLE 2. Summary of crystallographic data and refinement results for hydroxycalciomicrolite.

\begin{tabular}{|c|c|}
\hline Chemical formula & $\left(\mathrm{Ca}_{1.46} \mathrm{Na}_{0.15}\right)_{\Sigma 1.61}\left(\mathrm{Ta}_{1.72} \mathrm{Nb}_{0.28}\right)_{\Sigma 2.00} \mathrm{O}_{6}\left[(\mathrm{OH})_{0.65} \mathrm{~F}_{0.35}\right]$ \\
\hline Space group & $P 4_{3} 32(\# 212)$ \\
\hline$a(\AA)$ & $10.4205(1)$ \\
\hline$V\left(\AA^{3}\right)$ & $1131.53(2)$ \\
\hline$Z$ & 8 \\
\hline$\rho_{\text {cal }}\left(\mathrm{g} / \mathrm{cm}^{3}\right)$ & 6.020 \\
\hline$\lambda(\AA)$ & 0.71073 \\
\hline$\mu\left(\mathrm{mm}^{-1}\right)$ & 35.10 \\
\hline $2 \theta$ max. for data collection $\left(^{\circ}\right)$ & $\leq 69$ \\
\hline No. of reflections collected & 6086 \\
\hline No. of independent reflections & 749 \\
\hline No. of reflections with $I>2 \sigma(I)$ & 497 \\
\hline No. of parameters refined & 35 \\
\hline$R$ (int) & 0.021 \\
\hline Final $R$ factors $[I>2 \sigma(I)]$ & $R_{1}=0.030, w R_{2}=0.051$ \\
\hline Final $R$ factors (all data) & $R_{1}=0.050, w R_{2}=0.044$ \\
\hline Goodness-of-fit & 1.11 \\
\hline
\end{tabular}

SAINT program (Bruker, 2007) was used for data collection and reduction. The intensity data were corrected for X-ray absorption by the multi-scan method using the Bruker program SADABS (Bruker, 2007). Observed systematic absence of reflections indicate the unique space-group

TABLE 3. Coordinates and displacements parameters of atoms for hydroxycalciomicrolite.

\begin{tabular}{|c|c|c|c|c|c|c|}
\hline Atom & Wyckoff & $X$ & $y$ & $z$ & occupancy & $U_{\text {eq }}$ \\
\hline Ta2 & $12 d$ & 0.375 & $0.37388(2)$ & $0.12388(2)$ & $0.86(2)$ & $0.0042(2)$ \\
\hline $\mathrm{Nb} 2$ & $12 d$ & 0.375 & $0.37388(2)$ & $0.12388(2)$ & $0.14(2)$ & $0.0042(2)$ \\
\hline Ta1 & $4 a$ & 0.125 & 0.125 & 0.125 & $0.89(2)$ & $0.0044(2)$ \\
\hline $\mathrm{Nb} 1$ & $4 a$ & 0.125 & 0.125 & 0.125 & $0.07(3)$ & $0.0044(2)$ \\
\hline Cal & $12 d$ & $0.6217(2)$ & $0.3717(2)$ & 0.375 & $0.972(19)$ & $0.0155(7)$ \\
\hline $\mathrm{Na} 1$ & $4 b$ & 0.625 & 0.625 & 0.625 & $0.31(3)$ & $0.008(2)$ \\
\hline $\mathrm{O} 3$ & $24 e$ & $0.2517(5)$ & $0.0592(5)$ & $0.2482(6)$ & 1 & $0.0124(11)$ \\
\hline $\mathrm{O} 2$ & $24 e$ & $0.4447(5)$ & $0.2507(5)$ & $0.2506(5)$ & 1 & $0.0103(10)$ \\
\hline F1 & $8 c$ & $0.481(3)$ & $0.481(3)$ & $0.481(3)$ & $0.35(9)$ & $0.016(8)$ \\
\hline $\mathrm{O} 1$ & $8 c$ & $0.5046(14)$ & $0.5046(14)$ & $0.5046(14)$ & $0.65(9)$ & $0.001(4)$ \\
\hline H1 & $8 c$ & $0.5538(18)$ & $0.5538(18)$ & $0.5538(18)$ & $0.65(37)$ & 0.03 \\
\hline Atom & $U^{11}$ & $U^{22}$ & $U^{33}$ & $U^{23}$ & $U^{13}$ & $U^{12}$ \\
\hline Тa2 & $0.0042(2)$ & $0.00422(17)$ & $0.00422(17)$ & $0.00172(12)$ & $0.00020(11)$ & $-0.00020(11)$ \\
\hline $\mathrm{Nb} 2$ & $0.0042(2)$ & $0.00422(17)$ & $0.00422(17)$ & $0.00172(12)$ & $0.00020(11)$ & $-0.00020(11)$ \\
\hline Ta1 & $0.0044(2)$ & $0.0044(2)$ & $0.0044(2)$ & $-0.00014(19)$ & $-0.00014(19)$ & $-0.00014(19)$ \\
\hline $\mathrm{Nb} 1$ & $0.0044(2)$ & $0.0044(2)$ & $0.0044(2)$ & $-0.00014(19)$ & $-0.00014(19)$ & $-0.00014(19)$ \\
\hline Cal & $0.0159(8)$ & $0.0159(8)$ & $0.0146(11)$ & $-0.0050(7)$ & $0.0050(7)$ & $0.0045(12)$ \\
\hline \multicolumn{7}{|l|}{$\mathrm{Na} 1$} \\
\hline \multicolumn{7}{|l|}{$\mathrm{O} 3$} \\
\hline \multicolumn{7}{|l|}{$\mathrm{O} 2$} \\
\hline \multicolumn{7}{|l|}{$\mathrm{F} 1$} \\
\hline \multicolumn{7}{|l|}{$\mathrm{O} 1$} \\
\hline H1 & & & & & & \\
\hline
\end{tabular}




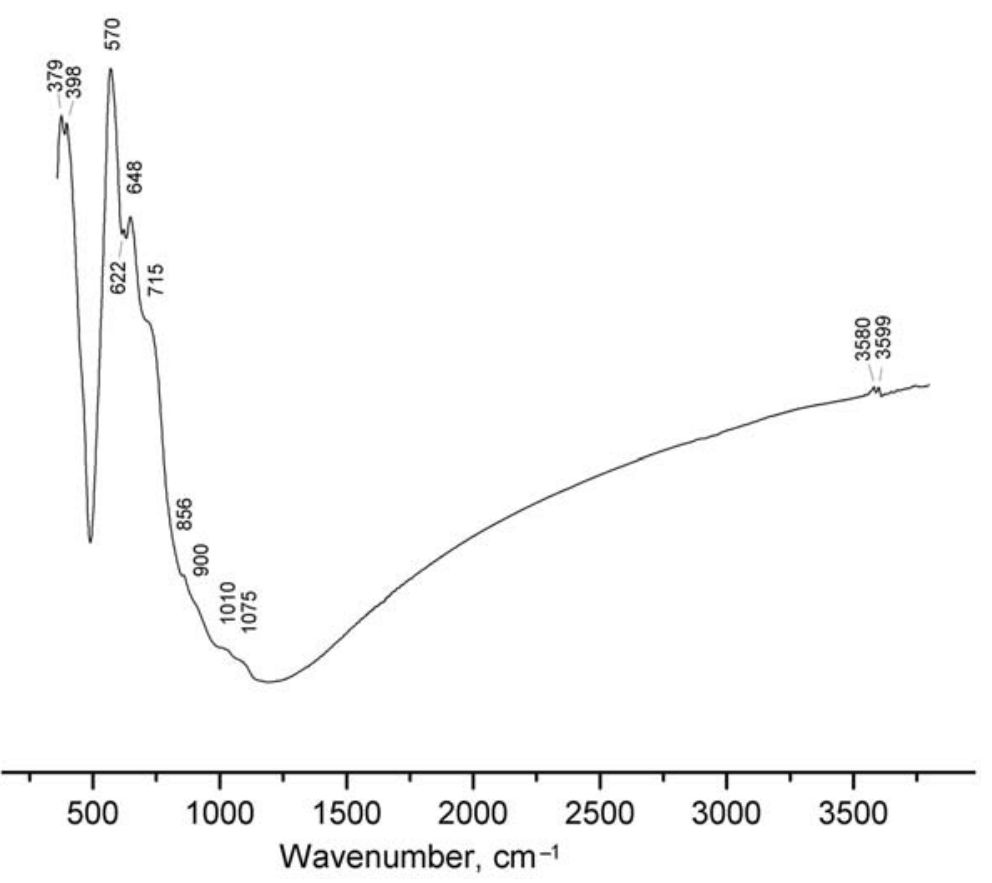

FIG. 3. Infrared spectrum of hydroxycalciomicrolite.

$P 4_{3} 32$ (\#212). The structure was solved and refined with SHELX97 (Sheldrick, 2008). The details for data collection and structural refinements are summarized in Table 2. Atomic coordinates and displacement parameters are listed in Table 3. A table of structure factors and a crystallographic information file have been deposited with the Principal Editor of Mineralogical Magazine and are available from http://www.minersoc.org/pages/e journals/dep_mat_mm.html.

Single-crystal neutron diffraction was carried-out to locate the $\mathrm{H}$ atom position with a Very Intense Vertical Axis Laue Diffractometer (VIVALDI) on a polychromatic thermal neutron beam (0.8-5.2 $\AA$ ) coupled with a large solid-angle (eight steradians) cylindrical image plate detector, at the High Flux reactor of the Institut Laue-Langevin in Grenoble, France (Wilkinson et al., 2002; McIntyre et al., 2006).

\section{Discussion}

\section{Infrared and Raman data}

The IR spectrum of hydroxycalciomicrolite (Fig. 3) shows two weak bands at 3580 and $3599 \mathrm{~cm}^{-1}$ that are attributable to $\mathrm{O}-\mathrm{H}$ stretching vibrations, indicative of very weak or almost no hydrogen bonding (Libowitzky, 1999). Weak bands at 856, 900,1010 and $1075 \mathrm{~cm}^{-1}$ correspond to overtones and combination modes. In general, $\mathrm{H}-\mathrm{O}-\mathrm{H}$ angle bending is associated with absorption peaks in the range $1500-1700 \mathrm{~cm}^{-1}$; their absence is consistent with all the hydrogen in hydroxycalciomicrolite present in $\mathrm{OH}$ groups. Recently, Andrade et al. (2013b) performed IR analysis and detected the bands at similar positions within experimental error, 3600 and $3581 \mathrm{~cm}^{-1}$ for fluorcalciomicrolite $(F d \overline{3} m)$.

The Raman bands related to $\mathrm{O}-\mathrm{H}$ stretching vibrations are located at 3586 and $3614 \mathrm{~cm}^{-1}$ for hydroxycalciomicrolite (http://ruff.info/R130269) and at $3582 \mathrm{~cm}^{-1}$ for fluorcalciomicrolite (http:// rruff.info/R120127) (Fig. 4).

\section{Crystal structure}

Hydroxycalciomicrolite is the first pyrochloresupergroup $\left(A_{2} B_{2} X_{6} Y\right)$ mineral exhibiting $\mathrm{P}_{3} 32$ symmetry (Fig. 5), instead of $F d \overline{3} m$. The presence of weak reflections violating the $F$-lattice was observed from both X-ray (4850 reflections, average $\mathrm{I} / \sigma(\mathrm{I})=2.82)$ and neutron diffraction 


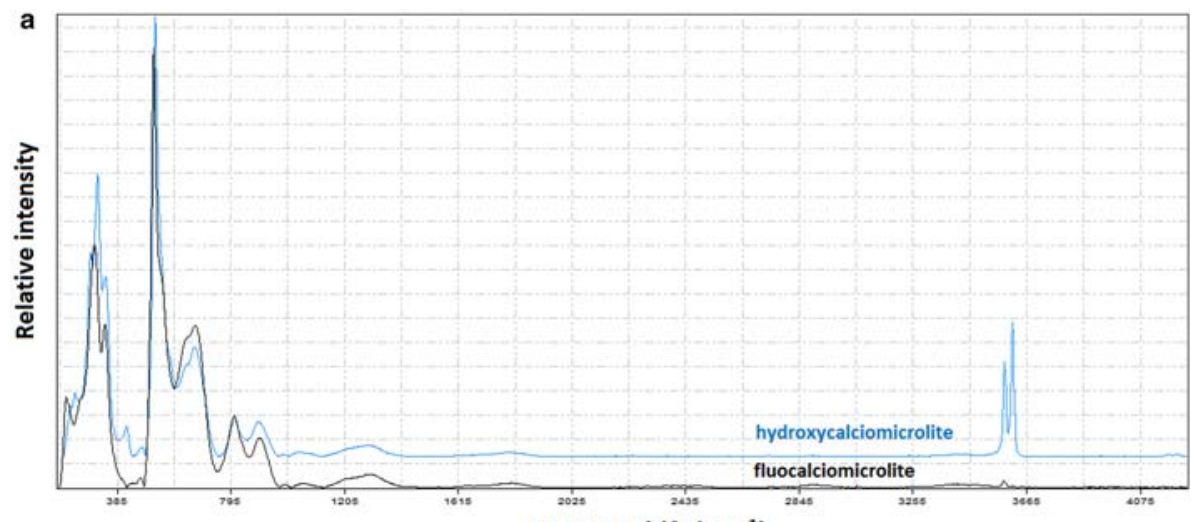

Raman shift $\left(\mathrm{cm}^{-1}\right)$

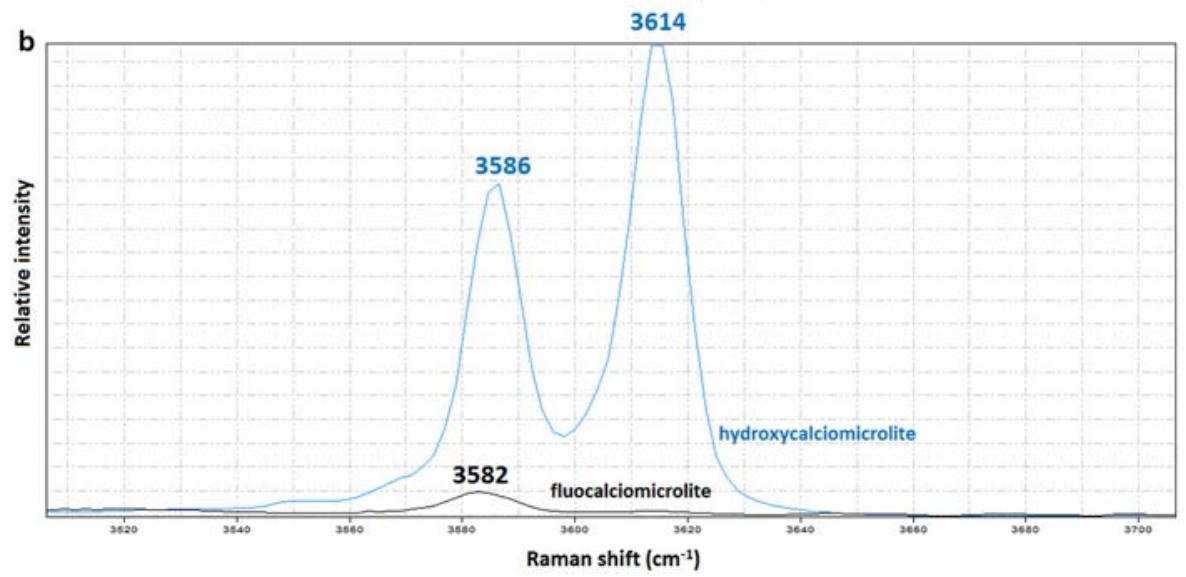

FIG. 4. (a) Raman spectra of hydroxycalciomicrolite (R130269), along with that of fluorcalciomicrolite (R120127) for comparison. (b) Detailed view of the $\mathrm{OH}$ region.

(4136 reflections, average $\mathrm{I} / \sigma(\mathrm{I})=1.16)$, about $70 \%$ and $80 \%$ of the total, respectively. The lowering of symmetry from the $F$ - to $P$-lattice is associated with the ordering of $\mathrm{Ca}$ cations and vacancies at the $A$ site. Such symmetry change has also been observed in the synthetic compounds $\mathrm{Ca}_{1.5} \mathrm{Ta}_{2} \mathrm{O}_{6} \mathrm{~F}$ and $\mathrm{Ca}_{1.5} \mathrm{Nb}_{2} \mathrm{O}_{6} \mathrm{~F}$ (Le Berre et al., 2007). In contrast, fluorcalciomicrolite has the space group $F d \overline{3} m$ (Andrade et al., 2013b) and does not show the same number of weak reflections violating the $F$-lattice symmetry. The lack of ordering in the type fluorcalciomicrolite is probably due to the low vacancy concentration in the $A$ site: the empirical formula is $\left(\mathrm{Ca}_{1.07} \mathrm{Na}_{0.81} \square_{0.12}\right)_{\Sigma 2.00}$ $\left(\mathrm{Ta}_{1.84} \mathrm{Nb}_{0.14} \mathrm{Sn}_{0.02}\right)_{\Sigma 2.00}\left[\mathrm{O}_{5.93}(\mathrm{OH})_{0.07}\right]_{\Sigma 6.00}\left[\mathrm{~F}_{0.79}\right.$ $(\mathrm{OH})_{0.21}$ (Andrade et al., 2013b). However, other occurrences may have lower $\mathrm{Na}$ content and more vacancies, so species with $P 4_{3} 32$ or other lower- symmetry space group may yet be discovered. Space group itself is not a reason to separate a mineral species. There are many minerals having different symmetries within the same mineral species (e.g. analcime, lazurite, vesuvianite etc.).

Additionally, the band splitting for the $\mathrm{OH}$ stretching vibrations, 3580 and $3599 \mathrm{~cm}^{-1}$ for IR (Fig. 3) and 3586 and $3614 \mathrm{~cm}^{-1}$ for Raman (Fig. 4), is related to the two distinct local environments for $\mathrm{OH}$ (e.g. vacancy $v s$. Na), and hence short-range order.

The structural model was refined in space group $\mathrm{P}_{3} 3$ 32. The atoms $\mathrm{Ta} 1, \mathrm{Nb} 1 \mathrm{Ca} 1, \mathrm{Ta} 2$ and $\mathrm{Nb} 2$, were refined anisotropically. The preliminary refinement showed that $\mathrm{Ca}$ and $\mathrm{Na}$ are ordered into the $\mathrm{Ca} 1$ and $\mathrm{Na} 1$ sites, respectively. The final refinement converged with the $\mathrm{Na}$ content greater than that determined by the electron microprobe 


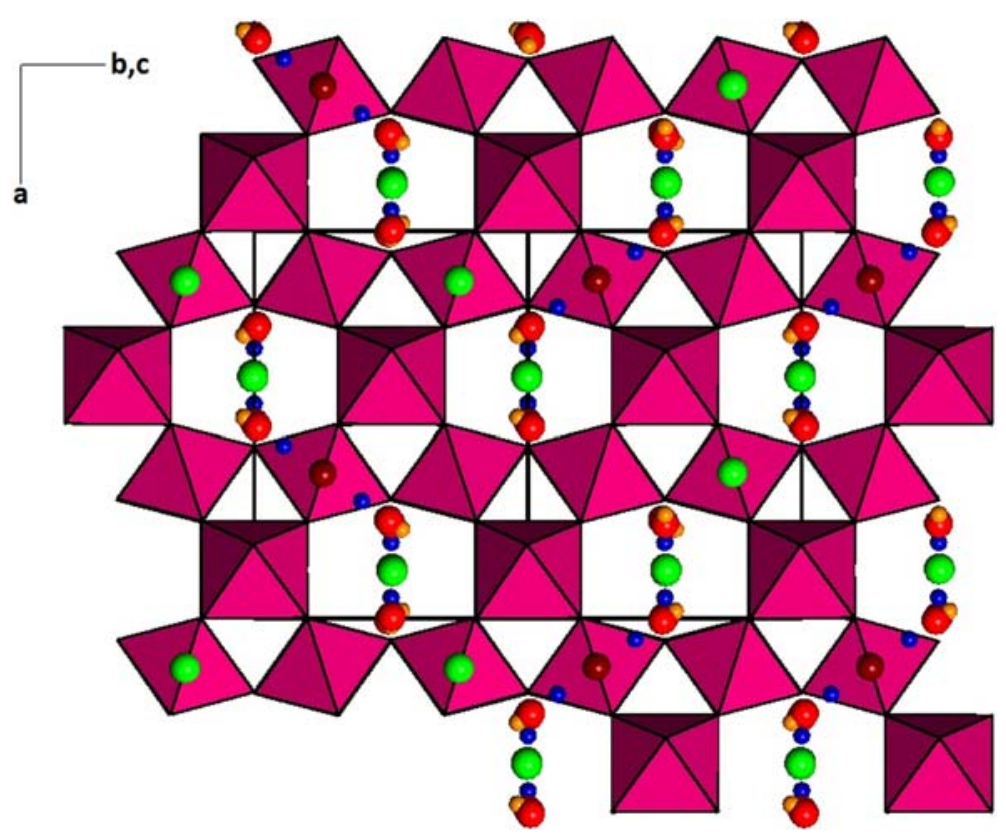

FIG. 5. Crystal structure of hydroxycalciomicrolite. Pink octahedra: $\mathrm{TaO}_{6}$ groups, green spheres: Ca1 cations, brown spheres: Na1 cations, red spheres: $\mathrm{O} 1$ anions, orange spheres: F1 anions and dark blue spheres: H1 atoms.

analysis. This difference may be due to volatilization of sodium during the chemical analysis. Final atomic positions are given in Table 3 and selected bond lengths, bond angles and bond-valence sums in Table 4. Using the parameters published by Brese and O'Keeffe (1991), the empirical bond valences of the refined model have been calculated using the cation-site occupancies of Table 3. The bond-valence sums for $\mathrm{O} 1$ ( 0.80 valence units without $\mathrm{H} 1$ ) confirm that this oxygen atom is $\mathrm{OH}^{-}$. The atoms Na1, (F1, O1), O2 and $\mathrm{O} 3$ were refined only isotropically due to the weak intensity of the reflections responsible for space group $P_{4} 32$. In the refinement, the pyrochlore $\left(A_{2} B_{2} X_{6} Y\right), Y$ site was split into two mutually exclusive nonequivalent sites, F1 and O1, separated by $0.43 \AA$. Also, the bond angles can be used to differentiate $\mathrm{F} 1$ from O1. The bond angle Ca1-F1-Ca1 is $115.84(92)^{\circ}$ (Table 4), so $\mathrm{F} 1(\mathrm{Ca} 1)_{3}$ is nearly planar triangular, while $\mathrm{Ca} 1-\mathrm{O} 1-\mathrm{Ca} 1$ is $106.30(64)^{\circ}$ and the $\mathrm{O} 1(\mathrm{Ca} 1)_{3}$ is a trigonal pyramidal, as expected for $\mathrm{OH}$. Overall, each $(\mathrm{O} 1, \mathrm{~F} 1)$ is surrounded by a tetrahedron of three Ca1 and one $(\square, N a 1)$. The very short $\mathrm{Na} \cdots \mathrm{H}$ distance of $1.28 \AA$ implies that there is a short-range ordering such that if the Na1 site is occupied, the nearest two $Y$ sites must be $\mathrm{F}$, not $\mathrm{OH}$, while if $Y$ is $\mathrm{OH}$, then the nearest $\mathrm{Na}$ site must be vacant. Moreover, during the structural refinement, it was found that the crystal was twinned by inversion (twin law: [100/0 $10 / 00 \overline{1}]$ ) with a ratio of $0.70: 0.30$ for the two twin components. The morphological and optical indications for twinning were absent, so it is microtwinning with the sizes of non-twinned blocks below the wavelength of visible light. The twinning by inversion is relatively common in the space group $\mathrm{P}_{3} 32$.

As heavy atoms are present within the structure, we investigated the position of hydrogen atoms present in the hydroxycalciomicrolite by means of single-crystal neutron diffraction. The VIVALDI diffractometer, that operates in Laue symmetry, was selected because of its high-intensity white-beam radiation that allows for faster data collection and use of smaller sample volume $\left(<1 \mathrm{~mm}^{3}\right)$. The unit-cell parameters with $\mathrm{P}_{3} 32$ space group and non-hydrogen atom coordinates were based on single-crystal $\mathrm{X}$-ray diffraction data. The reflections allowed in $P$ but forbidden in the $F$-lattice centre were extremely weak. However, after some cycles of refinement with neutron data it was possible to locate the hydrogen atom at the Wyckoff position $8 c(0.5519,0.5519,0.5519), \sim 1 \AA$ from the O1 atom in the difference-Fourier map of nuclear 
TABLE 4. Selected bond distances, bond angles and calculated bond-valence (BV) sums (in valence units) for hydroxycalciomicrolite.

\begin{tabular}{|c|c|c|c|}
\hline Bond & Bond length $(\AA)$ & $\mathrm{BV}$ & $\Sigma$ \\
\hline Ca1-F1 & $2.160(11)$ & $0.144(\times 2)$ & 0.288 \\
\hline $\mathrm{Ca} 1-\mathrm{O} 1$ & $2.287(10)$ & $0.266(\times 2)$ & 0.532 \\
\hline $\mathrm{Ca} 1-\mathrm{O} 2$ & $2.583(5)$ & $0.184(\times 2)$ & 0.368 \\
\hline $\mathrm{Ca} 1-\mathrm{O} 2$ & $2.638(5)$ & $0.158(\times 2)$ & 0.316 \\
\hline $\mathrm{Ca} 1-\mathrm{O} 3$ & $2.683(6)$ & $\begin{array}{c}0.140(\times 2) \\
\Sigma\end{array}$ & $\frac{0.280}{1.784}$ \\
\hline Na1-F1 & $2.60(5)$ & $0.009(\times 2)$ & 0.018 \\
\hline $\mathrm{Na} 1-\mathrm{O} 3$ & $2.678(6)$ & $\begin{array}{c}0.029(\times 6) \\
\Sigma\end{array}$ & $\frac{0.174}{0.192}$ \\
\hline (Ta1,Nb1)-O3 & $1.965(6)$ & $\begin{array}{c}0.882(\times 6) \\
\Sigma\end{array}$ & $\frac{5.292}{5.292}$ \\
\hline$(\mathrm{Ta} 2, \mathrm{Nb} 2)-\mathrm{O} 2$ & $1.979(5)$ & $0.849(\times 2)$ & 1.698 \\
\hline$(\mathrm{Ta} 2, \mathrm{Nb} 2)-\mathrm{O} 2$ & $1.993(5)$ & $0.818(\times 2)$ & 1.636 \\
\hline$(\mathrm{Ta} 2, \mathrm{Nb} 2)-\mathrm{O} 3$ & $1.955(5)$ & $\begin{array}{c}0.907(\times 2) \\
\Sigma\end{array}$ & $\frac{1.814}{5.148}$ \\
\hline O1-Ca1 & $2.287(10)$ & $0.266(\times 3)$ & 0.798 \\
\hline O1-H1 & $0.89(2)$ & $\begin{array}{c}0.302 \\
\Sigma\end{array}$ & $\frac{0.302}{1.100}$ \\
\hline F1-Ca1 & $2.160(11)$ & $0.144(\times 3)$ & 0.432 \\
\hline F1-Na1 & $2.60(5)$ & $\begin{array}{c}0.009 \\
\Sigma\end{array}$ & $\frac{0.009}{0.441}$ \\
\hline $\mathrm{O} 2-(\mathrm{Ta} 2, \mathrm{Nb} 2)$ & $1.979(5)$ & 0.849 & 0.849 \\
\hline $\mathrm{O} 2-(\mathrm{Ta} 2, \mathrm{Nb} 2)$ & $1.993(5)$ & 0.818 & 0.818 \\
\hline $\mathrm{O} 2-\mathrm{Ca} 1$ & $2.583(5)$ & 0.184 & 0.184 \\
\hline $\mathrm{O} 2-\mathrm{Ca} 1$ & $2.638(5)$ & $\begin{array}{c}0.158 \\
\Sigma\end{array}$ & $\frac{0.158}{2.009}$ \\
\hline $\mathrm{O} 3-(\mathrm{Ta} 2, \mathrm{Nb} 2)$ & $1.955(5)$ & 0.907 & 0.907 \\
\hline O3-(Ta1,Nb1) & $1.965(6)$ & 0.882 & 0.882 \\
\hline $\mathrm{O} 3-\mathrm{Ca} 1$ & $2.683(6)$ & 0.140 & 0.140 \\
\hline O3-Na1 & $2.678(6)$ & $\begin{array}{c}0.029 \\
\Sigma\end{array}$ & $\frac{0.029}{1.958}$ \\
\hline $\begin{array}{l}\text { Ca1-F1-Ca1 } \\
\text { Ca1-O1-Ca1 }\end{array}$ & $\begin{array}{c}\text { Bond-angles }\left({ }^{\circ}\right) \\
115.84(92) \\
106.30(64)\end{array}$ & & \\
\hline
\end{tabular}

density. Unfortunately, a complete refinement based on neutron data was not possible due to the weak intensity of the forbidden $F$-lattice reflections. The $\mathrm{H}$-atom position found with neutrons was incorporated in the model based on X-ray diffraction.

The refinement of this model converged to $R_{1}=$ $0.030, w R_{2}=0.051$, and the charge-balanced chemical formula obtained was $\left(\mathrm{Ca}_{1.46} \mathrm{Na}_{0.15}\right)_{\Sigma 1.61}$ $\left(\mathrm{Ta}_{1.72} \mathrm{Nb}_{0.28}\right)_{\Sigma 2.00} \mathrm{O}_{6}\left[(\mathrm{OH})_{0.65} \mathrm{~F}_{0.35}\right]$. For simplicity, the structure was refined with the scattering factors of $\mathrm{Ca}, \mathrm{Na}, \mathrm{Ta}, \mathrm{Nb}, \mathrm{O}, \mathrm{F}$ and trace elements such as $\mathrm{Mn}$ and $\mathrm{Sn}$ were ignored because of their negligible effects on the refinement. Apart from the site splitting noted previously, there is no longrange order of $\mathrm{F}$ and $\mathrm{OH}$. The $\mathrm{O} 1-\mathrm{H} 1$ vector is located along the threefold axis defined by O1-F1. The short $\mathrm{O} 1-\mathrm{H} 1$ distance $(0.89 \AA)$ and very long next-nearest $\mathrm{O} 3 \cdots \mathrm{H} 1(2.78 \AA)$ imply that there is no significant hydrogen bonding.

\section{Acknowledgements}

We acknowledge FAPESP (processes 2011/22407-0 and 2013/03487-8), CNPq from the Brazilian government and Science Foundation Arizona for financial support. We also thank Dr. Kenneth Domanik (University of Arizona) for his advice about microprobe analysis and Dr. Garry McIntyre (Australian Nuclear Science and Technology Organization) for his suggestions about neutron diffraction data.

\section{References cited}

Andrade, M.B., Atencio, D., Chukanov, N.V. and Ellena, J. (2013a) Hydrokenomicrolite, $\left(\square, \mathrm{H}_{2} \mathrm{O}\right)_{2} \mathrm{Ta}_{2}(\mathrm{O}$, $\mathrm{OH})_{6}\left(\mathrm{H}_{2} \mathrm{O}\right)$, a new microlite-group mineral from Volta Grande pegmatite, Nazareno, Minas Gerais, Brazil. American Mineralogist, 98, 292-296.

Andrade, M.B., Atencio, D., Persiano, A.I.C. and Ellena, J. (2013b) Fluorcalciomicrolite, $(\mathrm{Ca}, \mathrm{Na}, \square){ }_{2} \mathrm{Ta}_{2} \mathrm{O}_{6} \mathrm{~F}$, a new microlite-group mineral from Volta Grande pegmatite, Nazareno, Minas Gerais, Brazil. Mineralogical Magazine, 77, 2989-2996.

Atencio, D., Andrade, M.B., Christy, A.G., Gieré, R. and Kartashov, P.M. (2010) The pyrochlore supergroup of minerals: nomenclature. The Canadian Mineralogist, 48, 673-698.

Belezkij, W. (1956) Mineralização tântalo-estanífera e uranífera do minicípio de São João del Rei, Minas Gerais. Divisão de Fomento da Produção Mineral, Rio de Janeiro, Boletim 99, 142.

Brese, N.E. and O'Keeffe, M. (1991) Bond-valence parameters for solids. Acta Crystallographica, B47, 192-197.

Bruker (2007) APEX2, SAINT and SADABS. Bruker AXS Inc., Madison, Wisconsin, USA.

Francesconi, R. (1972) Pegmatitos da região de São João del Rei, Minas Gerais. PhD thesis, Universidade de São Paulo, São Paulo, Brazil.

Francesconi, R., Svisero, D.P. and Valarelli, J.V. (1976) Minerais de elementos raros no distrito pegmatítico de São João del Rei, Minas Gerais. Gemologia, 22(4445), 53-63.

Guimarães, D. (1948) Age determination of quartz veins and pegmatites in Brazil. Economic Geology, 43, $100-118$. 
Guimarães, D. (1950) A jazida de djalmaíta, de Volta Grande, Rio das Mortes, Minas Gerais. Anais da Academia Brasileira de Ciências, 22, 51-71.

Guimarães, D. and Belezkij, W. (1956) The stannotantalo-uraniferous deposits and occurrences in the region of São João del Rei, Minas Gerais, Brazil. International Conference on the Peaceful Uses of Atomic Energy, Proceeds 6, 143-146.

Guimarães, D. and Guedes, S.V. (1944) Nota preliminar sobre a região estanífera de São João del Rei, Minas Gerais. Divisão de Fomento da Produção Mineral, Rio de Janeiro, Avulso, 58.

Guimarães, D. and Guedes, S.V. (1946) Relatório da Diretoria, 1944. Divisão de Fomento da Produção Mineral, Rio de Janeiro, Bo1etim 77, 72-78.

Heinrich, E.W.M. (1964) Tin-tantalum-lithium pegmatites of the São João Del Rei district, Minas Gerais, Brazil. Economic Geology, 59, 982-1002.

Jercinovic, M.J., Williams, M.L., Allaz, J. and Donovan, J.J. (2012) Trace analysis in EPMA. [EMAS 2011: 12th European Workshop on Modern Developments in Microbeam Analysis IOP Publishing] IOP Conf. Series: Materials Science and Engineering, 32, https://doi.org/10.1088/1757-899X/32/1/012012

Le Berre, F., Crosnier-Lopez, M.P., Galven, C., Fourquet, J.L., Legein, C., Body, M. and Buzaré, J.Y. (2007) $\mathrm{Ca}^{2+} /$ vacancies and $\mathrm{O}^{2-} / \mathrm{F}$ ordering in new oxyfluoride pyrochlores $\mathrm{Li}_{2 \mathrm{x}} \mathrm{Ca}_{1.5-\mathrm{x}} \square_{0.5-\mathrm{x}} \mathrm{M}_{2} \mathrm{O}_{6} \mathrm{~F}(\mathrm{M}=\mathrm{Nb}, \mathrm{Ta})$ for $0 \leq \mathrm{x} \leq 0.5$. Dalton Transactions, 23, 2457-2466.

Lumpkin, G.R. and Ewing, R.C. (1995) Geochemical alteration of pyrochlore group minerals: pyrochlore subgroup. American Mineralogist, 80, 732-743.

Libowitzky, E. (1999) Correlation of O-H stretching frequencies and $\mathrm{O}-\mathrm{H} \cdots \mathrm{O}$ hydrogen bond lengths in minerals. Monatshefte für Chemie, 130, 1047-1059.

McIntyre, G.J., Lemée-Cailleau, M.H. and Wilkinson, C. (2006) High-speed neutron Laue diffraction comes of age. Physica B: Condensed Matter, 385, $1055-1058$.

Miura, H. (2003) CellCalc: A unit cell parameter refinement program on windows computer. Journal of the Crystallographic Society of Japan, 45, 145-147.

Peixoto, F. and Guimarães, D. (1953) Problemas de Cronogeologia. Universidade de Minas Gerais (Belo Horizonte), Escola de Engenharia, Instituto de Pesquisas Radiológicas, Publicação 1.

Pereira, R.M., Ávila, C.A., Neumann, R., Netto, A.M. and Atencio, D. (2003) Borda de hafnão zirconífero em zircão hafnífero da mina do Volta Grande, Província pegmatítica de São João Del Rei, Minas Gerais, Brasil. Boletim do Museu Nacional, Nova Série, Geologia, 69, 1-14.
Pereira, R.M., Netto, A.M., Ávila, C.A., Barrueto, H.R., Neumann, R. and Atencio, D. (2004) Zirconiferous hafnon and hafniferous zircon from São João Del Rei, Minas Gerais, Brazil. Pp. 919-922 in: Applied Mineralogy (Pechio et al., editors). 8th International Congress on Applied Mineralogy, Águas de Lindóia, setembro de 2004 v. 2.

Pereira, R.M., Ávila, C.A., Neumann, R., Netto, A.M. and Atencio, D. (2002) Hafnão zirconífero e zircão hafnífero na área da mina do Volta Grande, Província Pegmatítica de São João Del Rei, MG. XLI Congresso Brasileiro de Geologia, João Pessoa, Paraíba, Anais, p. 605.

Pinto, H.S.D. (2000) Pyrochlore der Pegmatit-Provinz Nazareno/Brasilien. PhD thesis, Johannes GutenbergUniversität, Mainz, Germany.

Pires, F.R.M. and Cabral, A.R. (1998) The Volta Grande pegmatites, Minas Gerais, Brazil; an example of rareelement pegmatites exceptionally enriched in lithium and rubidium: discussion. The Canadian Mineralogist, 36, 1157-1160.

Pires, F.R.M. and Pires, H.L. (1992) Regional zoning in the São João del Rei pegmatite district and its relation with the collisional Santa Rita granite, Minas Gerais, Brazil. Anais do $37^{\circ}$. Congresso Brasileiro de Geologia (São Paulo), 1, 269-272.

Quéméneur, J.J.G. (1987) Petrography of the pegmatites from Rio das Mortes valley, southeast Minas Gerais, Brazil. Revista Brasileira de Geociências, 17, 595-600.

Quéméneur, J. and Lagache, M. (1994) La holmquistite de Volta Grande prés de São João del Rei, Minas, Gerais, Bresil: caractéristiques chimiques et minéralogiques. Geonomos, 2(2), 15-21.

Quéméneur, J. and Lagache, M. (1999) Comparative study of two pegmatitic fields from Minas Gerais, Brazil, using the $\mathrm{Rb}$ and $\mathrm{Cs}$ contents of micas and feldspars. Revista Brasileira de Geociências, 29, $27-32$.

Quéméneur, J. and Vidal, P. (1989) Primeiras datações radiométricas dos granitos da região de São João dei Rei (MG). Simpósio de Geologia de Minas Gerais, Anais do $5^{\circ}$. 50-59.

Rolff, P.A.M.A. (1948) A província estanífera do Rio das Mortes. Revista da Escola de Minas, Ouro Preto, 13 (3), 5-10.

Sheldrick, G.M. (2008) A short history of SHELX. Acta Crystallographica, A64, 112-122.

Wilkinson, C., Cowan, J.A., Myles, D.A.A., Cipriani, F. and McIntyre, G.J. (2002) VIVALDI-A thermalneutron Laue diffractometer for physics, chemistry and materials science. Neutron News, 13, 37-41. 